Article

\title{
Folklore in China: Past, Present, and Challenges
}

\author{
Juwen Zhang ${ }^{1,2}$ \\ 1 Department of Japanese and Chinese, Willamette University, Salem, OR 97301, USA; juwen@willamette.edu \\ 2 School of Sociology, Beijing Normal University, Beijing 100875, China
}

Received: 2 April 2018; Accepted: 10 April 2018; Published: 13 April 2018

\begin{abstract}
This article first outlines the long history of folklore collection in China, and then describes the disciplinary development in the 20th century. In Section 3, it presents the current situation in terms of disciplinary infrastructure, development, contribution, and challenge, with a focus on the recent practice of safeguarding Intangible Cultural Heritage. These accounts are largely based on the views of the Chinese folklorists. In the final section, this article discusses the issues of cultural continuity, integration, and self-healing mechanisms in Chinese culture by putting Chinese folkloristics in a historical and world perspective. This paper suggests that, to understand Chinese folklore and culture, one must be aware of the most basic differences between Chinese fundamental beliefs and values and those of the West, and that Chinese folklore and folkloristics present new challenges to the current paradigms put forward in the post-colonial, post-modern, and imperial ideologies.
\end{abstract}

Keywords: Chinese folklore; Chinese folkloristics; folklore collection; folklore categorization; disciplinarity; Intangible Cultural Heritage in China

\section{Introduction}

The goal of this article is four-fold: (1) to outline the distinctive stages of folklore collection, categorization, and use in Chinese history; (2) to examine the rise and development of folkloristics in China; (3) to understand Chinese folkloristics in its broad cultural context; and (4) based on the Chinese case, to discuss the role of folkloristics "at the very center of humanistic study" (Wilson 1988, p. 158).

This article is intended to use the Chinese case as an interpretative framework in an international context to make sense of the development of folkloristics in China. Such an interpretive approach is based on these principles: (1) Since "the question of identity has always been central in folklore studies" and "at the heart of the folkloristic project" (Oring 1994, pp. 221-23, 226), we will look at Folklore as the dynamic process of maintaining identity (i.e., group-based individual, collective, and/or national identity) within a broad cultural entity; (2) The vitality of folklore practice lies in its mechanism of maintaining the fundamental beliefs and values in the culture, a mechanism that must be inclusive and dynamic to allow it to keep its self-healing competence in order to survive and thrive when facing vital social changes.

The central question in this interpretive account of Chinese folklore and folkloristics is: What role does folklore play in the process of maintaining a culture-such as that of the Chinese-that is ancient (e.g., at least since the Oracle Bone Inscriptions from 1600 BCE) and is characterized by diverse beliefs, languages, and customs? To answer this question, this article stresses the distinctive uses or functions of folklore in Chinese history, in addition to the universal functions of folklore (e.g., Bascom 1954), by paying attention to both its social and cultural contexts. Throughout the article, "folklore" is used to mean practices; "folkloristics" or "folklore studies" refers to the discipline.

Western (mostly in the English language) folkloristic survey of Chinese folklore has been limited. It began in the 1930s, departing from the previous missionaries' works which, nevertheless, do have 
historical values as part of the five-century history of Sinology (Honey 2001). Previous descriptions and studies related to Chinese folklore were for various goals and played a fundamental role in the Western understanding of China, for example, writings by the Jesuit Matteo Ricci (1552-1610), Dutch historian of religion Jan Jakob Maria de Groot (1854-1921) (De Groot 1892-1910), and German sociologist of religion Max Weber (1864-1920) (Weber 1968). However, the turn of the 1930s marked a different approach to folklore per se. The folklorist R. D. Jameson (1895-1959) pioneered this path with his teaching in China, the well-quoted Three Lectures on Chinese Folklore (Jameson 1932), and a survey of Chinese folklore in addition to at least two hundred entries in the Fund and Wagnalls Standard Dictionary of Folklore, Mythology and Legend (Jameson 1949). Wolfram Eberhard (1909-1988) published his Typen Chinesischer Volksmärchen (Eberhard 1937). Chinese local folklorists also began their folklore investigation (Chao 1942). China's societal and political changes in the 1950s-1970s aroused a new look from the West on the use of folklore in "red China" (Moy 1952; Yen 1964; Hrdličková 1965; Eberhard 1970; Eminov 1975). After the resuming of Chinese folkloristics in the 1980s, publications on Chinese folklore have tremendously increased. Local reflections upon the three decades of achievements, difficulties, and challenges (An and Yang 2015) depict a general picture of Chinese folkloristics. Surveys from American perspectives on the use of folklore and ideology (Tuohy 1991) and changes in the new century with emphasis on ethnic minorities (Bender 2006) provide another new look. The folklore of the Chinese abroad has also become a subject matter (Zhang 2006). These efforts have provided a background for this article.

\section{A Historical Overview of Folklore Collection in China}

Writing down folklore in China began as early as the 17th century BCE when Oracle Bone Inscriptions-from which the current Chinese writing system originated-were widely used to divine and record the everyday events in the life of the Kings (Chang 1980; Song [1994] 2005). From the 6th to the 3rd centuries BCE, all classics essential to Chinese culture (including folklore) were written down, including the Book of Rites (Liji), Book of Changes (Yijing), Book of Songs (Shijing), and the Classic of Mountains and Seas (Shanhaijing). These classics, in addition to their political and social functions, also set up a model of collecting and categorizing folklore. This tradition continued until the beginning of the 20th century when folkloristic efforts developed a new use of Chinese folklore, that is, by using it to construct a national identity in an international context.

The long history of collecting, recording, categorizing, editing, and (re)printing folklore presented a "written" history of folklore in contrast to the "practiced" history of folklore in China. This dynamic relationship contributed to the interactive working system of orthodoxy (as the ruling and unifying ideology through texts) and orthopraxy (as the unifying norm of constructing common national and cultural identities in everyday practices, based on regional, linguistic, belief, and social differences). As a result, a long-lasting unified Chinese culture developed, which is described as a model of "diversity within unity" (Watson and Rawski 1988) or the "pattern of diversity in unity" (duoyuan yiti geju) (Fei [1988] 1999, pp. 15, 38). Folklore in China thus has functioned as a centripetal force not only for informing Chinese culture as a whole within geographic China, but also for the fluid "Cultural China" (Tu 1994; Li 1995), in which Chinese cultural influence reaches beyond geographic, linguistic, religious, and ancestral limits.

In understanding "folklore in China" or "Chinese culture as a whole," one must bear in mind that: (1) The Chinese people have never been a homogenous group in terms of lineage or kinship, language or dialect, and religion or belief. Therefore, the racial/ethnic model of defining cultural "folk" or "group" must be abandoned; (2) "Chinese culture as a whole" is inclusive by nature, due to its basis in polytheist belief and practice, in contrast to those cultures based on a monotheist system. In addition, the following historical facts must also be considered: (A) Many groups of people with different cultures in China's history either no longer survive or are no longer known by their original group names, although their cultural elements are sometimes still discernable in Chinese culture; (B) Records from two thousand years ago already showed the kinds of cross-cultural and cross-continent 
interactions, including intermarriage, that were common within any country or continent, while recent genomic scientific discoveries further prove the common origin of human beings; (C) Western colonial concepts of "race" and "ethnicity" (ethno; ethnie) were not introduced to China until the early 20th century. (D) The current 56 nationalities (minzu; or "ethnic groups") in China were identified only in the second half of the 20th century. This has caused great confusion in a semantic sense as well as in political and social domains, although those 56 cultural groups existed long before the identification movement (minzu shibie). Therefore, folklore in China proves that it is folkloric identity, based on common folklore practice, rather than common "racial/ethnic" features, that plays the role of unifier in maintaining "Chinese identity" and Chinese culture as a whole. Folklore studies, therefore, should first look at the development and change of folklore traditions. This way of viewing folklore traditions brings in its wake a needed paradigm shift (Zhang 2015, 2017a).

\subsection{Uses of Folklore}

Prior to the formation of Chinese folkloristics in the early 20th century, folklore in China had been extensively collected and categorized. Some of the uses of folklore are no different from those seen in other cultures. However, one crucial difference between the Chinese and the Western use of folklore originated more than two thousand years ago: folklore was used to implement ethical guidelines in polytheist China, whereas laws deriving from monotheist religions were used to regulate society in Judeo-Christian cultures. This is still seen in the modern ideological conflicts between Western rule-of-law societies and the Chinese human-ruled (renzhi) or ritual/custom-ruled (lizhi) society.

For most of the 20th century, the use of folklore collection was primarily considered from a functionalist perspective, which represented "a paradigm absent in earlier diffusionist and literary approaches to folklore" (Oring 1996, p. 656). The four primary functions of folklore summarized by the functionalist William Bascom (Bascom 1954) are often developed to address different examples: in "amusement" with "deeper meaning" and in the "concepts of compensation and the escape mechanism" [or, escaping from repressions imposed by society, and providing a release of personal anxiety, wonder or fantasy, often by means of entertainments]; "in validating culture, [and] in justifying its rituals and institutions" [or, maintaining social norms]; "in education, particularly, but not exclusively, in non-literate societies" [or, education of local and traditional knowledge]; and "maintaining conformity to the accepted patterns of behavior" [or, applying social pressure and exercising social and political control in community-binding] (Bascom 1954, pp. 343-46). Such a functionalistic "explanatory model was wholeheartedly accepted by folklorists in their attempts to explain their own peculiar subset of sociocultural phenomena" (Oring 1976, p. 70). What is becoming more and more evident is the importance of folklore in constructing national identity in the modern world, especially in the current globalizing age.

Folklore in Chinese history gave prominence to two aspects in addition to Bascom's four key functions, and has resulted in a folklore that has maintained the social norms and unity for a much longer time and at a much larger social scale: (1) the temporal (i.e., folklore in China as a synchronic force to maintain the continuity of a culture without changing its fundamental beliefs and values for so many centuries); and (2) the spatial (i.e., folklore in China as a diachronic force to integrate many different cultural groups into one umbrella-culture based on the Confucian ultimate principle of "harmonizing with differences" (he er bu tong).

\subsection{Developmental Stages}

The first folkloristic effort to outline the long history of folklore collection in China appeared as The History of Chinese Folklore (Zhongguo minsu shi), published in six volumes in 2008. The leading figure behind this effort was Zhong Jingwen (1903-2002), who is regarded as the founder of Chinese folkloristics, and his work was completed by his student, Fang Xiao, who is Professor of Folklore at Beijing Normal University. The series covers the development of folklore collection from the pre-history (e.g., the Hemudu Culture about seven thousand years ago in China) to 1949, with commentaries 
on all important collections in each dynasty. It confirms that the terms "lore" (su), "social-lore" (shisu), "common-lore" (xisu), and "current-lore" (fengsu), were used very much as today's "folklore" (minsu) as early as the 5th century BCE. This series also presents a general categorization of Chinese folklore, a categorization which has guided all folkloristic textbooks in China since the 1980s, including: (1) material folklore; (2) social folklore; (3) spiritual folklore; and (4) linguistic folklore. Under these primary categories further sub-categories are developed: material production (or modes of production); material life (foodways, dressing and housing); social organization (religious and other societies); annual festivals; life-cycle rituals; folk beliefs; folk technology and craftsmanship; folk literature; folk language; folk arts (music, dance, drama and handicraft); and folk games and entertainments.

Using this work as a guide, folklore collection in China can be chronologically outlined in the following stages by highlighting the distinctive aspects and their continuity. This structural arrangement is essential to show the continuity of the long history prior to the 20th century, as seen in the Introduction to Folkloristics (Zhong [1998] 2009) edited by Zhong Jingwen:

1. The pre-Qin period (prior to the 3rd c. BCE). The character of "lore" (su) can be traced to the Bronze Inscriptions widely appearing from the 11th-3rd c. BCE. By the 5th c. BCE, the meaning of $s u$ was similar to today's usage. During this period, the fundamental beliefs and values in Chinese culture were established through everyday folklore practices, and were extensively discussed in all the major classics written at that time. This period is described as the "blossoming of a hundred schools of thought," but the most influential ideas were Confucian and Daoist (with Buddhist ideas integrated later on)—and are still essential to folklore practices today.

Confucius (551-479 BCE) interpreted myths of origin by relating them to human history, and, furthermore, differentiated the human from animals by making sense of the ethical relationship among human beings in the society-an ethical system deeply rooted in Chinese culture from individual life (friendship or brotherhood) to familial life (between husband and wife and father and son), and to social life (between different strata of society). Indeed, the Confucian ethical system has guided everyday folklore practices and united the different regional, linguistic, and ethnic practitioners through orthodoxy (text) and orthopraxy (practice) in China. His idea of promoting ethical behavior by ritualizing everyday behaviors as customs and by teaching through music (with songs/poetry) exemplified the use of folklore for individuals to become integrated into society and for the society to reinforce social norms.

Furthermore, his follower Xunzi (325-238 BCE), developed the idea of using folklore as a way of social ruling, that is, folklore as a unifier not only for small/familial groups, but for a state. He also pointed out that the primary difference between the Xia people (or the Han-Chinese) and the surrounding groups (or, today's shaoshu minzu, "ethnic minorities,") was only in lifestyle choices (e.g., manner of dress), rather than the political system or blood ties. Such Confucian views revealed that the ancients recognized the differences of lifestyle among different groups, but considered that they were changeable with ethical education and adaptable to each other's customs. Xunzi's student, Han Feizi (275-233 BCE), developed the idea that changing customs was the basis of changing social rules. This idea also proved the importance of folklore in unifying a state and improving social norms. The ancient ideas of "Great Unity" (dayitong) and "following local customs" (ruxiang suisu) are still discernable in today's folklore practice, and the following folk expressions are still common in contemporary language: "almost" (chabuduo), "giving face (to each other)" (gei mianzi), or the idea of "seeking common ground and letting differences exist" (qiutong cunyi).

The central Daoist insight regarding folklore is that it is essential to maintain the nature of human beings so that they can enjoy their existing customs developed through living a spontaneous life. This informed an ancient theory of "ideal life" which provided an outlet, escape, or compensation for those who were frustrated by the stricter Confucian guide to "enter the world." Some of the ancient Daoist ideas were further developed into a religion by the 3rd century, which, in turn, preserved many earlier myths and tales as the justification of a worldview and a metaphysical super-construction. 
These two views, along with others in Chinese history (e.g., Buddhist ideas became widespread by the 3rd-4th), exemplified the idea of "diversity in unity" through different interpretations of diverse folklore practices. This inclusive model of adopting other ideas and folklore is also key to understanding the mechanisms of transmitting and transforming traditions, and of cultural self-healing in Chinese history.

2. Compiling and annotating folklore collections during the Han and Wei Dynasties (3rd c. BCE-5th c.). The integration of the "three-teaching-in-one" (Confucianism, Daoism, and Buddhism) during this period reshaped Chinese folklore and culture, both ideologically and practically. However, Buddhism added more ritual forms and everyday explanations (e.g., reincarnation and karma) to the previous Chinese fundamental beliefs of "the immortality of the soul" and "the unity of man and nature," rather than changing them. Besides the influence of the classics mentioned above, historiographies became essential not only to the history of the Great Tradition, but also to collecting and maintaining folklore within the Little Tradition. The earliest and the greatest example is the Records of the Grand Historian (Shiji) by Sima Qian (145-90 BCE). In Sima Qian's view, history was related, but not equal, to folklore. Thus, he collected myths and legends to supplement his account of history. As a result, he established a model of historiography for the following twenty-four dynasties till the early 20th century, a continued series of historiographies including aspects of folklore. In those orthodox history books, folklore became a category alongside of categories such as "family history," "regional history," and "legendary history." This mutually supportive relationship between history and folklore is still characteristic of Chinese scholarship in the humanities.

Besides the historiography of the orthodox history in each dynasty, folkloregraphy (minsuzhi, a term further discussed below) has been a distinctive feature of Chinese folklore collection, often appeared in the form and name of local history: xianzhi (County Annals) or difangzhi (Local/Regional Annals). This tradition has continued since Sima Qian, and is still evident in the revision and writing of new xianzhi or difangzhi.

Two important examples of this tradition are the Disquisitions (Lunheng) by Wang Chong (27-97) and the Classics of Mountains and Seas (Shanhaijing) annotated by Guo Pu (276-324): the former is known as the representative work of atheist thought, and the latter as the most important source of myths in China. In his Disquisitions, Wang Chong discussed his views about folklore, in the context of the rise of Daoist and Buddhist ideas and the crisis of Confucian ideas during his time. He argued that folklore emerged out of actual experiences and was tested by history, and he criticized others for using folklore to serve their own political or ethical purposes. His view was welcomed because it considered that folklore should be treated as actual ways of living a life, but not necessarily determined by all kinds of gods and spirits. He denied his contemporary Daoist and Buddhist ideas about rebirth and karma.

As a Confucian and a Daoist scholar, as well as influenced by Buddhist ideas, Guo Pu helped justify the myths of origin for the believers. Through his annotations, the treasures of ancient myths were preserved and further developed in China and East Asia. The continuing influence of his book since his time shows how important his approach to folklore has been in Chinese culture and history.

Through such unorthodox folkloregraphies, there developed a rising category/genre of folklore around the 4th and 5th centuries: telling and recording (in writing) zhiguai (wonder and magic tales). The well-known Chinese versions of the tale types, "Swan Maiden" and "Cowherd and Weaving Girl," were recorded during this time. As a result, there began a history of using folkloregraphies to preserve the folklore excluded from orthodox historiographies, for example, In Search of the Supernatural (Gan 1996) (Soushenji) by Gan Bao (283-351) and the Records of Strange Things (Shuyiji) by Ren Fang (460-508).

3. The Tang and Song Dynasties (7th c.-13th c.). This period saw the prevalence of folklore about agricultural-political changes and the beginnings of recording urban folklore. With the 
"three-teachings-in-one" as the ruling ideology and the ritualized everyday ethical norms in an agricultural society, folklore functioned not only as a unifier of the newly expanded empire in political and social sense, but also as the medium integrating new cultural elements from Central Asian and Europe through the Silk Road, and from Southeast Asia and Eastern African through the maritime Silk Road. This period experienced the most diverse cultural interaction and integration in Chinese history, and perhaps also in human history by that time. For example, the extreme dualistic conflicts in the monotheist societies between the Christian and the Islamic ideas (e.g., the Crusades) resulted in both Christian and Islamic ideas, along with the migration of the believers, being integrated into Chinese culture and folklore. Various records and objects have revealed the integration of peoples from Africa, Europe, and other parts of Asia into the "Chinese people" during the Tang dynasty. It is this mechanism inherent in Chinese culture that has further energized its vitality, a phenomenon not possible in an exclusive monotheist society.

The development of paper-making and printing during this period further enriched the history of the two dynamic and interactive social classes: the elite with written literature and the folk/commoners with oral literature. Three encyclopedic collections ordered by the Emperors from that era are: Classified Collection of Arts and Literature (Yiwen Leiju) by Ouyang Xun (557-641); the Imperial Collection of the Taiping Era (Taiping Yulan); and the Extensive Records of the Taiping Era (Taiping Guangji) by Li Fang (925-996). They became models for similar collections in later times, including the national projects of three grand folk literature collections (folktales, folksongs, and proverbs) initiated in the 1980s. Widely circulated tales such as the "Predestined Wife" (Dinghundian, ATU 930A) and the "White Snake" (Baishezhuan), come from the Taiping Guangji. The well-known "Chinese Version of Cinderella" (Yexian, ATU 510A) was first collected in The Miscellaneous Morsels from Youyang (Youyang zazu) by Duan Chengshi (803-863). Some other important folklore collections include: Record of the Listener (Yijianzhi) by Hong Mai (1123-1202), the most comprehensive collection (in 420 volumes) of customs and strange tales in Chinese history; Records of the Entertaining Performances (Jiaofangji) by Cui Lingqin (fl. 740?); and, Notes of the Musical Performances (Bijimanzhi) by Wang Zhuo (1081-1161?) on folk drama, oral and musical performances.

Although many tales collected during this period exhibit clear Buddhist marks of Indian origin, a close look can tell something more. For example, in Archer Taylor (1959) seminal study of the "Predestined Wife," it was easy to tell that the match-maker or the Moon Man (yuexia laoren) in the tale was a prophet reading Sanskrit, which indicates that the Buddhist idea of fate was adopted into Chinese tales. In contrast, tracing the image of the match-maker, one can see that it was already widely used in Chinese literature and folklore as early as the 5th century BCE, long before Buddhism took root in China. What can be concluded from such examples is that, at least in the Chinese case, cultural integration was a long process based on its fundamental beliefs and values, and that foreign cultural elements were adopted often by changing names to reinforce those existing fundamental beliefs and values-a syncretic mechanism characteristic of Chinese culture (Zhang 2014, 2017a).

Recording urban folklore was also the result of developing metropolitan capital cities during this period, a new development of the traditional agriculture-centered folklore collection. Some of the important collections are: New Records of the Two Capitals (Liangjing xinji) by Wei Shu (?-757), Records of the Dreamy Luxury in the Capital (Dongiing menghualu) by Meng Yuanlao (1103?-1147?), Fantastic Stories of the Capital City (Ducheng jisheng) by Nai Deweng (fl. 1235), and Records of Dreamy Life (Menglianglu) by Wu Zimu (fl. 1274). They all vividly described the customs in the imperial courts and among the city residents, revealing the functions of education and justifying social norms through the imperial orders, as well as the lifestyle of the commoners who were still living on the agricultural calendar while transitioning to urban life. In addition, most traditional oral performances that still exist today in China were shaped and matured during this period.

4. The Yuan, Ming, and Qing Dynasties (1271-1911). The two striking characteristics of this period are: (a) multicultural interactions: the Yuan (1271-1368) was ruled by the Mongols, the Qing 
(1644-1911) by the Manchu, and the Ming (1368-1644) by the Han-Chinese; and (b) the extensive interaction of high and low cultures. During the Yuan and Qing, both elites and commoners among the Han-Chinese used folk literature and folklore as a way to escape the social pressure (e.g., the Han-Chinese were classified as the lowest social class by the Mongols) and to compensate their nostalgic sentiment. As a result, folk performances were unusually developed during the Yuan and the Qing. In addition, folklore was developed as a means of enlightenment and education, particularly during the Ming, when, for example, the West was first known to the Chinese on a large scale (i.e., through the Jesuit missionaries in the 16th and 17th centuries).

Folkloregraphy played an important role in maintaining the unity of the empire during this period. Writing and rewriting "regional annals" at county level all over the empire was the political task, while other records were also greatly encouraged. They were all compiled by the elites, who substantially used folklore and folklife materials. Thus, these records are considered very important to today's revitalization of local traditions. Furthermore, there were also "serendipitous" folklorists who, being scholar-officials at governmental or military posts, recorded folklore practices that turned out to be extremely valuable. For example, Xiao Daheng (1532-1612) was a general (and later the minister of defense) stationed at the border of the Ming Empire to defend against the Mongols. He wrote a booklet, The Records of Mongolian Folklore (Yisuji), which turned out to be the only written record of Mongolian folklore until the 20th century (Zhang 2017b).

Another development is the change of elite's attitude toward folk literature and arts, which led to more and more folkloregraphies being produced. Many works by Feng Menglong (1574-1646) demonstrated not only his comprehensive collections and recollections of folklore, but also his positive attitude toward folklore as a way of social education and entertainment. Pu Songling's (1640-1715) The Strange Tales from Liaozhai (Liaozhai zhiyi) is another classical collection of wonder or ghost stories (nearly 500 tales) in China.

The multicultural interactions in everyday life during this period also highlighted the value of languages in recording folklore practices. For example, Ancient Ballads and Proverbs (Guyaoyan) by Du Wenlan (1851-1881) and Records of Local Customs (Tufenglu) by Gu Zhangsi (fl. 1791?) recorded the popular expressions, folk sayings, and local slang, which greatly enriched the overall collection of linguistic folklore.

By the late 19th century, folklore collection had become more systemic with distinctive categorization, paving the road for the later folkloristic studies. At the same time, Western concepts such as "nation," "nationalism," "ethnology," "ethnography," and "folklore" began to be introduced into China. At the same time that China was resisting the colonial and imperial powers "scramble for China" after the Opium Wars of the 1840s, China was invaded by the imperialism of Western political and folklore terminology.

\section{Twentieth Century Folkloristics in a Nutshell}

Even though the history of folkloristics in China is short (since the 1910s), it has been severely interrupted during the wars against Japan's invasion (1931-1945), the Civil War (1945-1949), and the Cultural Revolution (1966-1976). These extreme times of cultural crisis also remind us how vulnerable the humanities can be when colonial invasions destroy a society.

There are different views about when the history of folkloristics in China actually began. However, these milestones are clear: the establishment of a (national) folklore society in 1927, its resumption in 1943, and the restoration/reestablishment of the China Folklore Society in 1983.

One view is that it began with such folklorists as Huang Zunxian (1848-1905, a scholar-official and diplomat known as "the first person who opens himself up to and embraces the world" in modern China) and Zhang Liangcai (1870-1906, whose Chinese Custom History (Zhang [1912] 2013) is known as the first monograph on Chinese social/folklore history). In the 1910s-1920s, university-based elites such as Cai Yuanpei, Lu Xun, Liu Bannong, and Shen Yimo further enabled the establishment of folklore studies in China. Eventually, in the 1930s, the following people were responsible for the 
establishment of the academic discipline of folklore studies: Zhou Zuoren, Jiang Shaoyuan, Gu Jiegang, Zhong Jingwen, and Lou Zikuang (Wang 2003, pp. 315-19).

Most Chinese folklorists, however, considered that the Folksong/Ballad (Folk Literature) Movement in 1918 connected folkloristics in China with the influence of European "nationalism." The Chinese wanted to use "folklore" to rescue the nation while facing their declining empire and the foreign invading powers, and as an effort to build a modern China (e.g., Hong 1985; Duara 1995). Many pioneering folklorists promoted these European ideas in China: evolutionism, social Darwinism, ethnology, sociology, and anthropology. Among them there were these schools of thoughts: (1) folklore as the weapon of an ideological revolution; (2) folklore as the tool of social reform; and (3) folklore as a force to expedite social changes with the involvement of the common people (e.g., promoting vernacular speech, baihuawen, to replace semi-classical usage that played a key role in Chinese culture). These thoughts were essential to the Folk Literature Movement and the May Fourth Movement or New Culture Movement in the 1910s-1920s, which were the turning points in modern China.

However, in reviewing the path of Chinese folkloristics from the 1910s, Bingzhong Gao (Gao 2008, p. 5) holds a different view. He considers that the discipline was substantially constructed during the 1980s-2010s, because it was only since the 1980s that the discipline began to take shape in these foundational areas: (1) teams of folklorists and their training through curriculum in universities; (2) folklore becoming public knowledge; and (3) folklore and folkloristics becoming part of cultural production.

This list of the pivotal events in the history of folkloristic studies since the 1910s may be helpful for the following discussion about the development, contributions, and challenges in current Chinese folkloristics:

1914: the term, minsuxue (民俗学, folkloristics), was first introduced into Chinese by Zhou Zuoren (1885-1987) by borrowing the characters from Japanese. Previously, "folklore" was translated into different Chinese terms such as "minjian wenxue" (folk literature), "minxue" (study of people/folk) and "geyaoxue" (study of ballads and songs).

1915: The journal, La Jeunesse (Xinqingnian), was launched and played a leading role in the New Culture Movement and the rise of folkloristics in China.

1918: The Beijing University Daily called for a national survey of ballads/folksongs, with the support of the university president, Cai Yuanpei (1868-1940), an event which is often seen as the beginning of folkloristics in China.

1922: Beijing University created Ballads/Folksongs Weekly (Geyao Zhoukan), which directly influenced the establishment of several associations or societies of folklore collection and studies.

1927: The Folklore Society was established in Sun Yat-sen (Zhongshan) University, and the journal Folklore Weekly was launched the following year.

1942: The multilingual journal, Folklore Studies (minsuxue zhi), was published in Beijing by Father Matthias Eder of Germany. (This journal was later moved to Japan as an English journal and renamed Asian Folklore Studies, and, currently, Asian Ethnology.)

1943: A seminar was held in Chongqing to announce the establishment of China Folklore Society, and the journal, Customs Collection (Fengwuzhi jikan), was published by the Society in the following year.

1950: China Folk Literature and Arts Association was established under the central government of the PRC. Folklore was included under the disciplinary field of Folk Literature and Arts. The journal, Folk Literature (minjian wenxue), was published.

1978: An open letter by a dozen leading folklorists was presented to the China Academy of Social Sciences proposing to restore Folkloristics in China.

1983: The China Folklore Society (CFS) was established in Beijing, and Zhong Jingwen was elected the President. CFS holds annual meeting, but does not have its own journal.

1984: The Ministry of Culture initiated the Three Grand Collections of Folk Literature Project: Chinese Folktales Collections; Chinese Ballads and Songs Collections; and Chinese Proverb Collections, with 
90 volumes at provincial level, and more than 4000 volumes at country level; all were published by 2009.

1985: The quarterly journal, Folklore Studies (Minsu yanjiu), was published in Shandong University, remaining a leading journal in the field.

1996: The International Asian Folklore Society was established in Beijing by scholars from China, Korea, Japan, Mongolia, and some other East and Southeast Asian countries. It is the only organization that connects East and Southeast Asian countries.

In writing the history of folkloristics in China, one view considers that it has undergone three stages: (1) Shaping stage (1918-1937); (2) Developing stage (1949-1966); and (3) Reconstructing stage (1976-present) (Xing 2016, pp. 415-28). Another approach is to see it as having the following two stages (Wang 2003, p. 342):

1. The beginning of folkloristic movement and studies of ancient folklore (1910s-1940s). Characteristic of this period were the national survey and ballad collection (or oral folklore), the publication of those collections, and the establishment of folklore societies in several universities. During this period, there was the pioneering stage (1918-1927) and foundation-laying stage (1927-1949). The publications included these categories: studies of ancient folk literature (e.g., Yang 1933; Hu 1923); studies of different folklore practices (e.g., Luobusangquedan 1918; Jiang 1928); and, introduction of Western folklore studies (e.g., Handbook of Folklore by C. Burne, English Folklore by A. R. Wright, and Le totémisme by M. Besson).

2. The establishment of folkloristic theories with Chinese characteristics (1950s-2000). The first three decades of this period were mostly occupied with the collection of folk literature and the survey of the oral literature of the minority nationalities. Since the late 1970s, folkloristics in China was developed with the (re)establishment of China Folklore Society, along with increasing folkloristic publications and introduction of Western folklore theories. In this process, more than ten Chinese folklorists published their own works within a dozen years to define and categorize folklore. Their commonly accepted categorization of Chinese folklore includes: economic folklore, social folklore, folklore of belief, folk literature (or folklore of language), and folklore of entertainment (i.e., games and sports).

Wang points out these additional features as he describes this developmental history (from the collections in the 5th century BCE to the early 21st century): from making use of folk practices to enhance political power to collecting folklore in texts for the broad goal of enhancing social harmony; from collecting folklore as an individual practice to institutionalizing it as a collective enterprise; and from making use of folklore to enable social and cultural integration to establishing a discipline "with Chinese characteristics" (Wang 2003, pp. 344-45).

\section{Current Situation}

The introduction of the concept of "Intangible Cultural Heritage" (ICH) through the UNESCO's ICH Convention (2003) to China marked a historical turn to folkloristics in China. However, to understand the present situation in China, one has to consider it as an organic development of the previous forty or so years. The current situation in China can be perceived from these aspects: disciplinary infrastructure; development and contributions; and challenges.

\subsection{Disciplinary Infrastructure}

Since the restoration of the China Folklore Society (CFS) in 1983, the discipline of folkloristics in China has enjoyed a rising tide as its usefulness is increasingly recognized in the construction of a new national identity of China in the world, as well as a new cultural identity for the Chinese at home and abroad. Folkloristics in China is symbolized through the CFS-in gaining recognition among other disciplines and in unifying folklorists, as well as in obtaining governmental support for folklorists to engage in various cultural heritage projects. The CFS functions as an umbrella scholarly institution 
with about 2200 members (as of spring 2017). In addition to its annual meetings, its online forum (http:/ / www.chinesefolklore.org.cn) also plays an important role in attracting young scholars and public folklorists.

At present (2017), there are 44 graduate degree programs in folklore/folk literature, seven of which are doctoral programs. On average, each folklore program has around 10-30 graduate students. However, there is no undergraduate major in folklore. A growing number of Master's Programs in Cultural Industry (wenhua chanye) now exist in more than one hundred universities and are closely related to folklore programs.

The establishment of graduate programs in Folkloristics (and Folk Literature) began in the 1980s, during the period of academic restoration. The first recipients of Ph.D. in Folklore were Dong Xiaoping and Tao Siyan in 1989 from Beijing Normal University (BNU). BNU is regarded as the cradle of contemporary folkloristics in China. Meanwhile, the first Ph.D. recipient in Ethnology was Zhuang Kongshao, who graduated from the Minzu University of China in 1988, followed by Zhou Xing as the first Ph.D. in Ethnology from China Academy of Social Sciences in 1989. The revival of Anthropology in China began in 1981 from Sun Yat-sen University, but it focused on sociology and archeology (a definition used at the university in the 1920s-30s when the discipline was first introduced to China), and did not include cultural/social anthropology until the late 1990s. Sun Yat-sen University began the Ph.D. in Folklore program in 2004.

Although "public folklore" is still a new concept in China for both academia and the government, there exists a national network of "public culture" posts: from the village level to the county, city, province (or autonomous regions), and the central government (i.e., Ministry of Culture) levels. This network has begun to function in the ICH movement in conjunction with folkloristic programs.

The leading journals in folkloristics are: Folklore Studies (Minsu yanjiu) published in Shandong University; Folk Culture Forum (Minjian wenhua luntan) by the Association of Folk Literature and Arts; Cultural Heritage (Wenhua yichan) by Sun Yat-sen University; and National Arts (Minzu yishu) by Guangxi Institute of Culture and Arts of the Nationalities. They are published in Chinese with the table of contents and abstracts in English.

Among the increasing folkloristic publications, two encyclopedic series are worth mentioning besides the above-mentioned Three Grand Collections of Folk Literature (China Folk Literature Collections Committee 1984-2009): Folklore and Folk Literature Series (ed. Lou [1970] 2004, a reprint of the folklore collections by the Folklore Society in the 1920s, amounting to 200 volumes), marking the foundation of folkloristics in China; and the Grand Series of Chinese Folklore (ed. Tao 2003-2004) in 31 volumes arranged by province, covering the studies and practices since the 1980s. There are also dictionaries and encyclopedias on regional or national folklore, based on previous literature or recent fieldwork.

Translations of international folkloristics have greatly contributed to the construction of folkloristics in China. Nearly all important theories and representative works in modern folkloristics have been introduced to China: from V. Propp's work on morphology to contemporary European fairy tale studies, from Kalevala to Yanagita Kunio's works, from E. Tylor's Primitive Culture to F. Boas' The Mind of Primitive Man, from European myth-ritual studies to American context and performance studies, from AT (ATU) Folktale Type Index to two indices on Chinese folktales (by W. Eberhard and $\mathrm{N}$. Ting), and from linguistic and semiotic studies to phenomenological and hermeneutic studies. Major American folklorists and their representative works have been translated into Chinese, including the writings by S. Thompson, R. Dorson, A. Dundes, D. Ben-Amos, R. Abrahams, R. Bauman, J. Brunvand, N. Ting, W. Eberhard, M. O. Jones, E. Oring, S. Sherman, L. Haring, B. Kirshenblatt-Gimblett, D. Kodish, and some others.

Writing the history of the discipline is another essential component of folkloristics. Besides the above-mentioned six-volume The History of Chinese Folklore (Zhong and Xiao 2008), there are also three books on the topic by Wang Wenbao (Wang 1987, 1995, 2003). They are supplementary to those major textbooks. Further, the improvement of the textbooks demonstrates the development of the discipline (Zhang 1985). For example, two key textbooks edited by Zhong Jingwen are being updated 
with new ideas: in the New Introduction to Folk Literature (Wan 2011), "fairy tale" is no longer a genre as it was in the Introduction to Folk Literature (Zhong 1980b); in the New Introduction to Folkloristics (Xing 2016), "folkloregraphy" and "image-narrative" (tuxiang xushi) are discussed without mentioning "ethnography" (minzuzhi) which was a key term in the Introduction to Folkloristics (Zhong [1998] 2009).

International exchanges among folklorists is another important aspect of the development of folkloristics in China. Beginning with interactions with Japanese folklorists in the 1980s, Chinese folklorists soon began to participate in seminars, summer schools, and conferences with European folklorists. Discrete and individual communications with American folklorists began in the 1980s, but institutional exchange between the China Folklore Society and the American Folklore Society did not begin until 2005 (Zhang and Song 2017). In the past decades, dozens of young folklorists have gone abroad as visiting scholars and/or as presenters at conferences. Still, there is a trend for the young folklorists to get degrees abroad and return to work in China. The role of Chinese folklorists on the world folklore stage is becoming important, whether in voicing their opinions or participating, even leading, international organizations or events, as described below.

Reflecting upon the development of folkloristics in China, Bingzhong Gao (Gao 2008, p. 5) points out that the present historical opportunity is based on these factors: (1) the economic and ideological reform in the 1980s; (2) folklore entering the urban and mainstream life from the rural and marginal groups; (3) folklore becoming the "intangible cultural heritage" in the ideological reconstruction at the state level in China; and (4) the international influence regarding post-modern thoughts, particularly through the UNESCO system.

In Gao's opinion, the central theory and method for folklore studies (mostly folk literature, or folktales) until the 1980s were based on the European "survival" theory, that is, by examining the object or literature that survived in text. However, substantial changes began in the 1990s, when folklore studies extended to contemporary texts and material life. Meanwhile, the new generation of folklorists (who earned Ph.D. in Folklore or Folk Literature in the 1990s) have explored and adopted theories from other disciplines, and self-reflected the history of folkloristics in China. The most meaningful progress is that Chinese folklorists have begun a new disciplinary orientation by focusing on "contemporary," "everyday life," and "common people" (Gao 2015, p. 7). These changes are highlighted in these specific research areas: (1) traditional festivals; (2) folk beliefs; and (3) intangible cultural heritage items.

This paradigmatic shift becomes clear with the rising team of folklorists across China and increasing publications emphasizing "the disciplinarity of folkloristics" in recent years. At present, Chinese folklorists have earned their status by voicing their opinions in public cultural affairs in the ICH movement. For example, based on the suggestions by the China Folklore Society in 2005 (via a committee led by the CFS President Liu Kuili), the Chinese central government changed the public holiday system in 2007 by making some traditional festivals become public holidays with days-off to accord with the traditions that the common people had celebrated for centuries (Xiao 2017).

\subsection{Development and Contributions}

Whether in the public or academic domain, "Chinese folklore" has experienced a transformation from the negative image of being "backward" or "superstitious" to being a "distinctive" or "traditional" part of diverse human cultures. The negative stereotype was developed mainly through the depiction by foreign missionaries or visitors prior to the mid-20th century. This depiction was internalized by the Chinese until the 1980s as is evident in many movies made in China the 1980s (e.g., the so-called "fifth generation" directors). Further, the stereotypes of the Chinese tradition and folklore were reinforced by ideological propaganda coming out of Hollywood movies (e.g., the image of Fu Manchu). As the world gets a better knowledge of China and Chinese culture, these images have recently begun to change. Folklore has certainly played a key role in this process.

However, "Chinese folkloristics" is little known throughout the world, as A. Dundes observed when he visited China in 1990 and subsequently wrote in the preface to the Chinese translation of his work in 2004 (i.e., The Interpretation of Folklore; see also, (Chen 2017; Hu 2017)). Language is indeed 
a mutual barrier for both Chinese and non-Chinese folklorists; limited face-to-face communication between Chinese and foreign folklorists is also a sad reality. However, there may be other reasons as well including the venues for such communication and the cultural attitudes toward each other. As Francis L. K. Hsu (Hsu 1973) pointed out about the effect of "white anthropology," there was the assumption among both white and non-white scholars that non-white anthropologists could at best only collect data, but could not analyze that data. As a result, in the volumes edited by European and American scholars on "world folklore/folkloristics" or related to "Chinese folklore/folkloristics," the descriptions lack either critical insight or relevant depth, and often are not written by Chinese experts on the topics. In fact, while major achievements in world folkloristics are constantly translated into Chinese, meaningful discussions and high theories explored in China are yet to be known to the rest of the world (Baron 2017).

Indeed, "Chinese folklorists have developed various refreshing and creative perspectives" (An and Yang 2015, p. 280), and they are certainly worthy of being recognized as contributions to world folkloristics. A brief exemplary list may provide a glimpse of these achievements:

- Delineating the goals of the discipline: focusing on current practices by common people in everyday life through folkloregraphy; a departure from the previous "survival" model and "looking down at" (xiangxiakan) the folk;

- Distinguishing folkloregraphy from ethnography (Xing 2016): a unique development of the approach to "documenting folklore" in contrast to "studying folklore" based on Zhong Jingwen's idea (Wang 2016; Gao 2007); a potential departure of the racial/ethnic-centered paradigm;

- Training folklorists through dozens of Folklore Programs in universities and other public culture departments: non-academically trained folklorists are being recognized as "public folklorists";

- Exerting influence on public education through folklore museums and on public policies through involvement in such social activities as the ICH movement;

- Establishing bachelor, master, and doctoral degrees in Cultural Industrial Management (wenhua chanye guanli, since 2004) as part of regular higher education, integrating folkloristics, public policies, enterprises, public culture, and cultural tourism;

- Expanding the scope of folkloristics to include and develop the following: video-documenting folklore in relation to visual anthropology; women-folklore (nüxing minsu) (Wang 2012; Xing 1995); eco-folklore (shengtai minsu) (Jiang 2003); performative folklore; folk culture (Wan 2010) and hometown folklore studies (An 2004);

- Strengthening theories with more systemic views on "mythologism" (Yang 2016), introduction and development of Propp's morphology of folktale (Li 1996; Liu 2010), tale-type (Qi 2007; Liu 2002; Ting 1978, 1974), folk fairy tale (Liu 1985), and folk narrative (Liu 2012, 2010; Lü and An 2006);

- Strengthening interdisciplinary studies by applying philosophical (Lü 2015), semiotic, religious studies, linguistic, and other disciplinary theories and methods; seeking "grand theories" and paradigm shifts (Wu 2015; Liu 2009);

- Localizing international folklore theories such as context and performance, myth studies, ritual studies, and (intangible) cultural heritage studies;

- Transforming folklore studies into a domain of public culture or culture heritage by bringing "everyday life" as the target as well as the means of folklore studies, so that common people become active subjects, rather than passive objects, of folklore traditions; and

- Participating in and organizing international conferences and collaborations such as initiating the International Asian Folklore Society (1996), and engaging in the CFS-AFS collaborative projects (since 2011). In this regard, Chinese folklorists have begun to move from the previous "being-translated" or "translating others" to a stage of "self-translating." See, for example, a Special Issue of the Asian Ethnology on "Chinese Folklore Studies toward Disciplinary Maturity" with Chinese folklorists' voice and reflection (An and Yang 2015, vol. 74.2), and a Special Issue of the Western Folklore on "Intangible Cultural Heritage in China" (Zhang and Zhou 2017, vol. 76.2). 
These dynamic discourses suggest that the most meaningful change is that Chinese folklorists are beginning to break away from the "self-inferior" mentality internalized through colonialism and racism, and to gain their self-confidence and equal attitude in exchanges about self and with others.

These aspects reveal the idea of establishing Chinese folkloristics "with Chinese characteristics," which was first proposed by Zhong (1980a). While the academic programs are growing and folklorists begin to participate in national cultural projects and policy-making, a few fundamental questions are still not well clarified or answered: What unique contributions can folkloristics make to humanistic studies, and to the construction of national identity? What are the immediate and ultimate goals for the discipline?

\subsection{Challenges}

The past forty years of restoration and reconstruction of folkloristics in China can be seen as a move "toward disciplinary maturity" with increasing disciplinary communication between Chinese and international folklorists (Li 2015). However, "many questions have also surfaced in terms of its theoretical discussions, disciplinary practices, and disciplinary orientation" (An and Yang 2015, p. 274). In discussing the challenges based on the current development, An and Yang take ideological and methodological aspects into consideration: within folkloristic studies, the theoretical orientation began to shift in the 1980s from previous "class struggle" and "revolution" views in collecting and studying folk literature to the "perspective on folklore as the everyday lived culture of the common people of a nationality" (An and Yang 2015, p. 278). This marks a useful advance for the discipline, that is, people studying people, as seen in the fact that terms like "folk," "folk culture," and "folklore" have entered the public discourse and everyday practice.

As is always the case with new social and academic developments, many challenges remain. They can be generalized in these areas:

1. Constructing disciplinary theories: Although many original ideas have been raised and discussed, there is lack of theorization. Many studies quote or are based on certain theories, but demonstrate a lack of understanding of the histories of those ideas.

2. Connecting academic and public folklore sectors: There is lack of such connection in both theories and practices. Although there is a nation-wide network of public culture services, folklorists have not properly and sufficiently engaged themselves in it, which also means that there is great potential for Chinese folklorists better to involve themselves in pubic folklore studies.

3. Seeking disciplinary orientation: Current discussions regarding where to look (i.e., to "look down $a^{\prime \prime}$ the folk or to "look backward at" the text), how to study everyday life (i.e., to take it as the means or the end for the discipline), and how to re-conceptualize "folk/common people" (or, "citizen") and "everyday life" have energized, as well as challenged the field.

4. Expanding disciplinary scope: Although the number and size of folklore programs across China are growing, some important areas are yet to be included in curriculum and research, or in interdisciplinary studies. For example, musical aspects in festivals and rituals, folklore and healing, folklore and law, and studies on marginalized groups such as the peasant-workers, and the newly urbanized groups should be included. There are still strong influences from literary, historical, and anthropological approaches in training researchers.

5. Broadening the horizon and vision: Many younger folklorists have demonstrated their interest in developing international communication and multidisciplinary approaches, but there is a long way to go to routinize these competences in training folklorists.

In An and Yang (2015) view, folkloristics in China remains at the periphery of the humanities and social sciences, and faces the following challenges. (1) The disciplinary orientation: How should folk literature (or text) be treated in relation to material folklore studies, as a subfield or not? (2) The secondary importance of folklore: With increasing popular interest in regional or case studies, 
the dominant ethnographic research method has resulted in the fact that those field descriptions of folklore in a specific community become a footnote to popular culture. (3) The continued overemphasis on the contrast between folklore and elite culture tends to mislead many folklorists as to the value of fieldwork and analyses. (4) There is a tendency to overcorrect the conventionally conducted text-centered research approach in the history of Chinese folklore studies. This, in turn, results in another undesirable approach in which context-based research attracts greater attention, whereas textual analysis is ignored. As Chinese folklorists are struggling with these issues, these same issues are, in fact, also challenges to folklorists worldwide.

The flourishing of folkloristics in China in the past decade or so has much to do with the concept of "Intangible Culture Heritage (ICH)." However, ICH has also presented unprecedented challenges. Key questions are: What are the essentials of ICH in China? What has made China and Chinese folklorists invest so much in the ICH movement? The ICH movement seems to have completely directed the research interests of the Chinese folklorists because most fundable research projects are $\mathrm{ICH}$ projects. Although the ICH practice in China reveals some of the substantial issues related to the transmission and transformation mechanism of Chinese traditions, it is, after all, an opportunity to reconstruct a national identity, and it provides China scholars a chance to gain an equal status in international discourse, and to unify the diverse cultural groups (or ethnic minorities, shaoshu minzu) in building a modern nation (Zhang 2017a).

Another big challenge is in differentiating "folklore," "folk literature," and "cultural heritage" (all are distinct "areas" of curricular focus in universities) through teaching and research project design (relating to funding). More specifically, due to limitations of the current curriculum in folklore programs, "fieldwork method" has not integrated the proper use of audio-visual recording (i.e., video documentation), and ethics has not been sufficiently emphasized in fieldwork and subsequent use of field collection. Students are admitted into folklore graduate programs through exams on designated textbooks with little connection to current issues. One common practice is that a student's MA or Ph.D. thesis is often limited to the topics along the lines of his or her advisor's specialties. Recently, there have been many theses or publications or projects on topics related to the ICH items, but none or few studies on some other important topics such as, migrant "peasant-workers" in urbans cities, "empty villages" with only young children and their grandparents, and foreigner (diaspora) communities in China. In addition, once an MA or Ph.D. student is enrolled, he or she will take courses for one to one and a half years, and then propose a topic to work on to graduate in three years-a limit with few exceptions.

There are only a handful of folkloristic journals, as mentioned above. This has much to do with the Chinese policy of ranking journals in relation to funding research projects, professional promotion, and disciplinary ranking. As a result, folkloristics is not recognized in the academic world as it should be. However, with the fast growth of Internet use or we-media, as well as the ICH movement, folklorists' works are getting better known, and their publications are easily accessible through the national database (e.g., www.ckni.com.cn, orckni.net).

The study of folklore in the Overseas Chinese communities regarding the continuity and change of Chinese cultural identity is also a challenge. The concept of "Cultural China" from philosophical (Tu 1994) and anthropological (Li 1995) perspectives has provided a valuable foundation. However, folkloristic studies on this topic are scarce (Zhang 2009, 2015). Perhaps the main reason is there are not enough scholars who have the linguistic competence as well as other resources to develop this meaningful area. However, a pioneering anthropological/folkloristic project supervised by Bingzhong Gao at Beijing University has enabled more than a dozen doctoral dissertations based on fieldwork abroad in the US and Southeast Asia in the past decade.

A hotly-debated issue among Chinese intellectuals concerns defining folklore (minsu) and nationality (minzu), ethnicity (minzu), and Chinese/China as a "nation" (minzu). The last three concepts are written using the same Chinese characters. This semantic problem emerged when "folklore" and "nationalism" were introduced from Europe and Japan at the beginning of the 20th century. Similarly, 
the disciplinary boundaries among folkloristics, anthropology, sociology, and ethnology in China are also complicated by the institutional hierarchy established with political orientation in the 1950s when European nationalism and Russian definition of "nationality" influenced the "ethnic identification" (minzu shibie) that resulted in the current 56 official "nationalities" in China (some scholars use "ethnic groups" instead of "nationalities"). Today, the issue is even more problematic because the previous concept of "minzu" has the colonial and racial connotations, while there now is a strong effort to promote "Chinese national identity" (i.e., all Chinese are of one nation without emphasizing the individual "nationalities").

Interestingly, all of the above-mentioned challenges are intensified in the current ICH movement in China. Studying the Chinese case may provide a meaningful reference for folklorists everywhere to reflect upon the very history and nature of folkloristics. For example, one ongoing debate is about the authenticity or the distinction between folklore and "fakelore" in identifying an Intangible Cultural Heritage item. In addition, commercializing or industrializing traditions is seen everywhere. In this sense, examining Chinese folklorists' involvement in the actual practices of identifying, protecting, heritagizing, industrializing, and localizing ICH items in China is essential to understanding the relationship between ICH and folkloristics. However, three reminders should be mentioned here (Zhang and Zhou 2017):

1. The ICH movement in China has provided a historical opportunity for Chinese culture to activate its self-healing mechanism after an extremely painful period of history from the mid-19th century (e.g., the Opium Wars) to the end of 20th century. The idea of inclusiveness with "Chinese characteristics" has accompanied the unprecedented growth of Chinese economy in the past four decades and has enabled the society and culture to demonstrate its cultural vitality.

2. Because of China's special relationship with the West since the Opium Wars, everyday life in Chinese society has experienced a distorted growth and has accumulated great negative social tensions and conflicts in the struggle of "westernization" or "modernization" versus "Chinese essence/tradition." With the introduction of the ICH concept following the emphasis on "root-seeking" or "reflection" from the 1980s, Chinese people begin to pay attention to cultural self-awareness, returning to their traditions, and rediscovering their historical and cultural roots (Fei 1997, 2003).

3. The ICH movement in China has not only provided a "timely" venue for alleviating domestic problems, but has also created an international opportunity, through which China is able to engage in both political and academic discourses. More meaningfully, the Chinese government has taken the opportunity to enable the public to revitalize traditions (e.g., festivals and temple fairs) and to change previous religious, cultural and economic policies (Zhou 2017). In particular, by constructing the "cultural industry," the government has greatly alleviated potential social, economic and ideological conflicts.

The practices and impacts of the ICH in China are probably unique in the world; China has appropriated the ICH concept and policies for its own political, social, and cultural agenda. It happens that this act has been in accordance with the inherent cultural transmission mechanism in Chinese history: localizing and syncretizing different cultural expressions. This is key to understanding folklore and folkloristics in contemporary China.

\section{Chinese Characteristics in Perspective}

Furthermore, to understand Chinese folklore and folkloristics, one vital question is, as mentioned above: What has enabled Chinese culture to sustain its vitality for more than three millennia? This question implies that there are "Chinese characteristics" in the continuity of the "Chinese culture," and that it is meaningful to examine these characteristics. To answer this question, two historical contexts must be considered: the history of "domestic" cultural integration with the belief of "harmonization 
with differences," and the history of encountering foreign colonial and imperial powers since the 16th century.

What sustains a culture must be the inherent vitality and the self-healing mechanism that is maintained by the practitioners who hold their fundamental beliefs and values as their cultural roots. The term "Chinese culture" has to be understood in a broad and dynamic sense, that is, a mixture of Confucian and Daoist beliefs and values as expressed in these aspects: (1) the immortality of the soul (e.g., ancestral worship); (2) the unity of man and nature (e.g., fengshui practice about position and location); (3) the Confucian "Great Unity" (e.g., orthopraxy versus orthodoxy; diversity within unity); (4) the importance of following local customs (e.g., Confucian virtues of respect); (5) the emphasis on harmony within differences (e.g., the inclusive three-teaching-in-one); and (6) the search for auspiciousness and the avoidance of inauspiciousness through the practice of zhanbu (e.g., fortunetelling or divination) (Zhang 2017a). Further, "China" is a "stream" that always has been changing, like a "living tree," embodying a "Cultural China" (Tu 1994; Li 1995).

The vitality of Chinese culture is rooted in those fundamental beliefs and values, and its self-healing mechanism enables people to regain cultural self-awareness when their culture falls into predicaments, to reaffirm self-confidence, to reach self-healing, and to eventually enter a new stage of development. The self-healing mechanism enables other cultures to be integrated, and, in turn, contributes to the flourishing and diversity of human cultures in the world. This self-healing mechanism also means that a culture is not only able to recover its roots in crisis, but also absorbs new cultural elements, develops them into its own, and further strengthens its vitality.

All of these concepts, however, are expressed through everyday practices. Therefore, folklore plays a key role in maintaining the Chinese cultural identity and unity. This mechanism can clearly be illustrated by considering the history of China since the 16th century.

The importance of considering China's history since the 16th century can be seen from these two-way influences: mostly material influence from China to Europe, and mostly ideological influence from Europe to China. Two historical facts may well symbolize this relationship: The first is the ideological influence from Europe. Ever since the Jesuit missionary Matteo Ricci (1552-1610) arrived in China in 1582, Christianity began to take root in China and began challenging traditional "Chinese culture." This has continued until today through the European ideologies of "colonialism," "imperialism," "modernization," and "universal values." Certainly, the missionaries' reports of Chinese culture to their European contemporaries also stimulated some European thinkers, such as the philosopher and mathematician G. W. Leibniz (1646-1716) and, later, Max Webber (1864-1920) and others. However, their comments on Chinese people and culture were for their own ideological systemization, and have greatly influenced Western understandings of China.

The other fact is that in 1607 the Dutch's East India Company shipped, for the first time, Chinese tea from Macau to Amsterdam, and thus began the tradition of tea drinking in Europe. The interest in tea further led to the introduction of some Chinese art forms, such as gardening, poetry, and music. Eventually, the material needs led to the Opium Wars, providing a shield for ideological conversion.

The interaction between China and the West (and Japan) since the 16th century began with very different purposes from both sides, and thus led to the essential conflicts of interests that climaxed in the century of wars from the 1840s to the 1940s. This century also saw the Chinese loss of self-confidence and self-awareness of their cultural roots. However, the inherent self-healing mechanism eventually led to the May Fourth/New Culture Movement in the 1910s-1920s when the substantial conflict between the two belief systems surfaced as the struggle between "westernization" and "maintaining national essence."

This ideological struggle continues today, as can be seen in the "searching for the roots" (xungen) movement in 1980s and the ongoing ICH movement. In reality, such a struggle is expressed through everyday folklore practices: defending tea as tradition in fighting against coffee; eating in neighborhood restaurants to fight against the Western fast-food chains; wearing traditional robes to restore the Han-Chinese traditions. However, as seen today in numerous streets, both traditional foods and 
western cuisines are popular, both tea and coffee businesses are growing, and all styles of dress are visible in everyday life. Clearly, Chinese people have never been more self-confident in their cultural roots over the past two centuries than they are today; they have regained the sense of "equal" exchange with the others in this globalizing age. What can be drawn from this reality is that the self-healing mechanism is strong in contemporary China, and is evident in these major aspects: the harmonization with differences, the heritagization and industrialization of ICH items, and the localization in accordance with harmonization (Zhang 2017a).

As a result, folklore and folkloristics, as well as the ICH practices in China, have helped answer, even partly, the core question in studying humanities: If we know that the continuity of a tradition lies in the hands of the practitioners (Bascom 1954, p. 343; Brunvand [1968] 1978, p. 1; Toelken 1979, p. 32; Glassie 1989, p. 31), how can we know what enables the practitioners to make a choice of absorbing or discarding other traditional elements (Zhang 2015, p. 467)?

Acknowledgments: I thank Dan Ben-Amos for encouraging me to finish this article, and for his comments along the way. I also thank Bingzhong Gao at Beijing University and Mark Bender at Ohio State University for their constructive suggestions. Bill Long of Salem, Oregon helped polishing the final draft, and the editors of this journal courteously refined it to the current state. I thank them sincerely, but all errors are mine.

Conflicts of Interest: The author declares no conflict of interest.

\section{References}

An, Deming. 2004. Hometown: A Pivot in Contemporary Chinese Folkloristics (Jiaxiang: Zhongguo xiandai minsuxue de yige qidian he zhidian). National Art (Minzu Yishu) 2: 25-31.

An, Deming, and Lihui Yang. 2015. Chinese Folklore since the Late 1970s: Achievements, Difficulties, and Challenges. Asian Ethnology 74: 273-90. [CrossRef]

Baron, Robert. 2017. First Impressions, Enduring Memories. In Metafolklore: Stories of Sino-US Folkloristic Communication. Edited by Juwen Zhang and Junhua Song. Guangzhou: Sun Yat-sen University Press.

Bascom, William. 1954. Four Functions of Folklore. The Journal of American Folklore 67: 333-49. [CrossRef]

Bender, Mark. 2006. Chinese Folklore. In The Greenwood Encyclopedia of World Folklore and Folklife. Edited by William Clements. 4 vols. Westport: Greenwood Press, vol. 2, pp. 211-33.

Brunvand, Jan Harold. 1978. The Study of American Folklore: An Introduction, 2nd ed. New York: W. W. Norton. First published 1968.

Chang, Kwang-Chih. 1980. Shang Civilization. New Haven: Yale University Press.

Chao, Wei-Pang. 1942. Modern Chinese Folklore Investigation. [Asian] Folklore Studies 1: 55-76, 79-88.

Chen, Jianxian. 2017. Alan Dundes's Visit to China. In Metafolklore: Stories of Sino-US Folkloristic Communication. Edited by Juwen Zhang and Junhua Song. Guangzhou: Sun Yat-sen University Press.

China Folk Literature Collections Committee. 1984-2009. The Three Grand Collections of Folk Literature in China (Zhongguo minjian wenxue sanda jicheng). Editor-in-Chief Zhou Yang. 298 vols. Beijing: Zhongguo ISBN Zhongxin. (Including, The Grand Collection of Folktales in China. The Grand Collection of Folk Songs in China. and The Grand Collection of Proverbs in China.)

De Groot, J. J. M. 1892-1910. The Religious System of China, Its Ancient Forms, Evolution, History and Present Aspect, Manners, Customs and Social Institutions Connected Therewith. 6 vols. Brill: The Dutch Colonial Government.

Duara, Prasenjit. 1995. Rescuing History from the Nation: Questioning Narratives of Modern China. Chicago: University of Chicago Press.

Eberhard, Wolfram. 1937. Typen Chinesischer volksmarchen. Helsinki: Academia Scientiarum Fennica.

Eberhard, Wolfram. 1970. The Use of Folklore in China. In Studies in Chinese Folklore and Related Essays. Bloomington: Indiana University Research Center for the Language Sciences, pp. 1-16. The article was a lecture in 1965.

Eminov, Sandra. 1975. Folklore and Nationalism in Modern China. Journal of the Folklore Institute 12: 257-77. [CrossRef]

Fei, Xiaotong. 1999. The Pattern of Diversity in Unity of Chinese Nation (Zhonghua Minzu Duoyuan Yiti Geju), rev. ed. Beijing: Minzu University of China Press. The lecture with the same title was given for the Tanner Lecture at the Chinese University of Hong Kong, 1988. 
Fei, Xiaotong. 1997. Reflection, Dialogue, and Cultural Self-Awareness (Fansi Duihua Wenhua zijue). Journal of Beijing University 3: 15-22.

Fei, Xiaotong. 2003. The Intellectual Origin and Practical Meaning of Cultural Self-Awareness (Wenhua zijue de sixiang laiyuan yu xianshi yiyi). Wenshizhe (Literature History Philosophy) 3: 15-16.

Gan, Bao. 1996. In Search of the Supernatural: The Written Record. Translated into English by Kenneth J. DeWoskin and James Irving Crump; Palo Alto: Stanford University Press.

Gao, Bingzhong. 2007. The Use and Current Meaning of Folkloregraphy and Ethnography (Minsuzhi yu minzuzhi de shiyong duiyu minsuxue de dangxia yiyi). Folk Culture Forum (Minjian Wenhua Luntan) 1: 29-32.

Gao, Bingzhong. 2008. The 30-Year Development of Chinese Folklore Studies (Zhongguo minsuxue sanshinian de fazhan lichen). Folklore Studies (Minsu Yanjiu) 3: 5-19.

Gao, Bingzhong. 2015. The New Ear of Chinese Folkloristics: Establishing a Discipline of Cultural Studies through Citizens' Everyday Life. Folklore Studies (Minsu Yanjiu) 1: 5-15.

Glassie, Henry. 1989. The Spirit of Folk Art. New York: Abrams.

Honey, David B. 2001. Incense at the Altar: Pioneering Sinologists and the Development of Classical Chinese Philology. New Haven: American Oriental Society.

Hong, Chang-Tai. 1985. Going to the People: Chinese Intellectuals and Folk Literature, 1918-1937. Cambridge: Harvard University Press.

Hrdličková, Věnceslava. 1965. The Professional Training of Chinese Storytellers and the Storytellers' Guilds. Archiv Orientalni 33: 225-48.

Hsu, Francis L. K. 1973. Prejudice and Its Intellectual Effect in American Anthropology: An Ethnographic Report. American Anthropologist 75: 1-19. [CrossRef]

$\mathrm{Hu}$, Pu'an. 1923. Customs All Over China (Zhonghua Quanguo Fengsu Zhi). 4 vols. Shanghai: Guangyi Shuju.

$\mathrm{Hu}$, Xiaohui. 2017. What a Pity: Alan Dundes Did Not Receive This Book. In Metafolklore: Stories of Sino-US Folkloristic Communication. Edited by Juwen Zhang and Junhua Song. Guangzhou: Sun Yat-sen University Press.

Jameson, Raymon De Loy. 1932. Three Lectures on Chinese Folklore. Peking: North China Union Language School.

Jameson, Raymon De Loy. 1949. Chinese Folklore. In Funk \& Wagnalls Standard Dictionary of Folklore, Mythology and Legend. Edited by Maria Leach. New York: Funk \& Wagnalls, pp. 220-27.

Jiang, Shaoyuan. 1928. Hair, Beard, and Nail: Superstitions about Them (Faxuzhao: Guanyu Tamen de Mixin). Shanghai: Kaiming Shudian.

Jiang, Fan. 2003. Eco-Folklore (Shengtai Minsuxue). Harbin: Heilongjiang Renmin Chubanshe.

Li, Yih-yuan. 1995. Notions of Time, Space and Harmony in Chinese Popular Culture. In Time and Space in Chinese Culture. Edited by Chun-Chieh Huang and Erik Zurcher. Leiden: E. J. Brill, pp. 383-98.

Li, Yang. 1996. A Morphological Study of Chinese Folktales. Shantou: Shantou University Press.

Li, Jing. 2015. Chinese Folklore Studies toward Disciplinary Maturity. Asian Ethnology 74: 259-72. [CrossRef]

Liu, Shouhua. 1985. Introduction to Chinese Folk Fairy Tales. Chengdu: Sichuan Minzu Chubanshe.

Liu, Shouhua. 2002. Chinese Folktale Type Studies (Zhongguo minjian gushi leixing yanjiu). Wuhan: Huazhong Shifan Daxue Chubanshe.

Liu, Xiaochun. 2009. From "folklore" to "contextual folklore": Shifting Paradigms of Chinese Folklore Studies (Cong minsu dao yujing zhong de minsu: Zhongguo minsuxue yanjiu de fanshi zhuanhuan). Folklore Studies (Minsu yanjiu) 2: 5-35.

Liu, Kuili. 2010. The Life Tree of Folk Narrative. Beijing: Zhongguo Shehui Chubanshe.

Liu, Shouhua. 2012. History of Folktale in China. Beijing: Shangwu yinshuguan.

Lou, Zikuang. 2004. Folklore and Folk Literature Series. Diancang Minsuxue Congshu. Edited by Chunsheng Ye. 3 vols. Harbin: Heilongiiang renmin chubanshe. First published 1970.

Lü, Wei. 2015. Folkloristics as a Great Discipline: Studies on the History and Logic of Paradigm Shift from Theoretical Reflections to Practical Science. Beijing: Zhongguo Shehui Kexue Chubanshe.

Lü, Wei, and Deming An. 2006. The Diversity of Folk Narrative. Beijing: Xueyuan Chubanshe.

Luobusangquedan. 1918. Annals of the Mongolian Customs. Translated into Chinese by Zhao Jingyang. 1988, as Menggu Fengsu Jian. Shenyang: Liaoning minzu chubanshe, Original in Mongolian, reprinted in 1981.

Moy, Clarence. 1952. Communist China's Use of the Yang-ko [Rice Sprout Dramas]. Papers on China VI: 112-48.

Oring, Elliott. 1976. Three Functions of Folklore: Traditional Functionalism as Explanation in Folkloristics. Journal of American Folklore 89: 67-80. [CrossRef]

Oring, Elliott. 1994. The Arts, Artifacts, and Artifices of Identity. Journal of American Folklore 107: 211-33. [CrossRef] 
Oring, Elliott. 1996. Functionalism. In American Folklore: An Encyclopedia. Edited by Jan H. Brunvand. New York and London: Garland Publishing, Inc., pp. 654-56.

Qi, Lianxiu. 2007. Chinese Ancient Folktale Type Studies (Zhongguo gudai minjian gushi leixing yanjiu). 3 vols. Shijiazhuang: Hebei Jiaoyu Chubanshe.

Song, Zhenhao. 2005. Xiashang Shehui Shenghuoshi. Beijing: Zhongguo Shehui Kexue Chubanshe. First published 1994.

Tao, Lifan. 2003-2004. Grand Series of Chinese Folklore (Zhongguo minsu daxi). 31 vols. Lanzhou: Gansu Renmin Chubanshe.

Taylor, Archer. 1959. The Predestined Wife (Mt. 930). Fabula 2: 45-82. [CrossRef]

Ting, Nai-Tung. 1974. The Cinderella Cycle in China and Indo-China. Helsinki: Suomalainen Tiedeakatemia.

Ting, Nai-Tung. 1978. A Type Index of Chinese Folktales. FF Communications No. 223. Helsinki: Suomalainen Tiedeakatemia.

Toelken, Barre. 1979. The Dynamics of Folklore. Boston: Houghton Mifflin.

Tu, Wei-Ming. 1994. The Living Tree: The Changing Meaning of Being Chinese Today. Palo Alto: Stanford University Press. Tuohy, Sue. 1991. Cultural metaphors and reasoning: Folklore scholarship and ideology in contemporary China. Asian Folklore Studies 50: 189-221. [CrossRef]

Wan, Jianzhong. 2010. Introduction to Chinese Folk Culture (Zhongguo minjian wenhua gailun). Beijing: Beijing Normal University.

Wan, Jianzhong. 2011. New Introduction to Folk Literature (Minjian wenxue xinbian). Shanghai: Shanghai Wenyi Chubanshe.

Wang, Wenbao. 1987. The Developmental History of Chinese Folkloristics (Zhongguo minsuxue fazhanshi). Shenyang: Liaoning Daxue Chubanshe.

Wang, Wenbao. 1995. A History of Chinese Folkloristics (Zhongguo minsuxue shi). Chengdu: Bashu Chubanshe.

Wang, Wenbao. 2003. A History of Chinese Folklore Studies (Zhongguo minsu yanjiushi). Harbin: Heilongjiang Chubanshe.

Wang, Weihua. 2012. The Spring Festival Customs and the Female Identity Awareness (Chunjie xisu yu nuxing shenfenyishi). Beijing: Shangwu Yinshuguan Guoji Youxian Gongsi.

Wang, Zhiqing. 2016. Folkloregraphy (Minsuzhi). In A New Introduction to Folkloristics. Edited by Li Xing. Beijing: Beijing Shifan Daxue Chubanshe, pp. 338-70.

Watson, James, and Evelyn Rawski. 1988. Death Ritual in Late Imperial and Modern China. Berkeley: University of California Press.

Weber, Max. 1968. The Religion of China. New York: Free Press.

Wilson, William A. 1988. The Deeper Necessity: Folklore and the Humanities. Journal of American Folklore 101: 156-67. [CrossRef]

Wu, Xiaoqun. 2015. Folkloristics: Disciplinarity and Paradigm (Minsuxue: xueke shuxing yu xueshu fanshi). Zhengzhou: Henan Daxue Chubanshe.

Xiao, Fang. 2017. The Predicament, Revitalization, and Future of Traditional Chinese Festivals. Western Folklore 76: 181-96.

Xing, Li. 1995. Chinese Female Folk Culture (Zhongguo nuxing minsu wenhua). Beijing: Zhongguo Dangan Chubanshe.

Xing, Li. 2016. A New Introduction to Folkloristics (Minsuxe gailuz xinbian). Beijing: Beijing Shifan Daxue Chubanshe.

Yang, Shuda. 1933. The Weddings and Funerals of the Han Dynasty (Handai hunsang lisu kao). Beiping: Shangwu Yingshuguan.

Yang, Lihui. 2016. My Re-interpretation of "Mythologism": Cause and Effect. Journal of Yangtze University 5: 1-7. Yen, Alsace C. 1964. Red China's Use of Folklore. Literature East and West 8: 72-87.

Zhang, Liangcai. 2013. Chinese Custom History (Zhongguo fengshu shi). Beijing: Zhongguo Renmin Chubanshe. First published 1912.

Zhang, Zichen. 1985. Chinese Folklore and Folkloristics (Zhongguo minsuyu minsuxue). Hangzhou: Zhejiang Renmin Chubanshe.

Zhang, Juwen. 2006. China Abroad. In The Greenwood Encyclopedia of World Folklore and Folklife. 4 vols. Edited by William M. Clements. Westport: Greenwood Press, vol. 2, pp. 233-45.

Zhang, Juwen. 2009. The Vitality and Validity in the Transmission of Tradition (传统传承中的有效性与生命力). Journal of Wenzhou University 22: 12-17.

Zhang, Juwen. 2014. Cultural Grounding for the Transmission of the "Moon Man" Figure in the Tale of the "Predestined Wife" (ATU 930A). Journal of American Folklore 127: 27-49. [CrossRef] 
Zhang, Juwen. 2015. Chinese American Culture in the Making: Perspectives and Reflections on Diasporic Folklore and Identity. The Journal of American Folklore 128: 449-75. [CrossRef]

Zhang, Juwen. 2017a. Intangible Cultural Heritage and Self-Healing Mechanism in Chinese Culture. Western Folklore 76: 197-226.

Zhang, Juwen. 2017b. The Records of Mongolian Folklore by Xiao Daheng (1532-1612) and Two Rhapsodies on the Xun-Flute from Tang China (618-907). Lewiston: Edwin Mellen Press.

Zhang, Juwen, and Junhua Song. 2017. Metafolklore: Stories of Sino-US Folkloristic Communication (Yaminsu: Zhongmei minsu xuezhe jiaoliu de gushi) (Chinese-English). Guangzhou: Sun Yat-sen University Press.

Zhang, Juwen, and Xing Zhou. 2017. Introduction: The Essentials of Intangible Cultural Heritage Practices in China: The Inherent Logic and Transmission Mechanism of Chinese Tradition. Western Folklore 76: 133-50.

Zhong, Jingwen. 2009. Introduction to Folkloristics (Minsuxue gailun), 2nd ed. Shanghai: Shanghai Wenyi chubanshe. First published 1998.

Zhong, Jingwen. 1980a. Establishing the discipline of folk literature research with Chinese characteristics (Jianli juyou Zhongguo tedian de minjian wenyixue). Ideological Front (Sixiang zhanxian) 5: 43-50.

Zhong, Jingwen. 1980b. Introduction to Folk Literature (Minjian wenxue gailun). Shanghai: Shanghai Wenyi Chubanshe.

Zhong, Jingwen, and Fang Xiao. 2008. History of Chinese Folklore (Zhongguo minsushi). 6 vols. Beijing: Remin Chubanshe.

Zhou, Xing. 2017. Folk Belief and Its Legitimization in China. Western Folklore 76: 151-66.

(C) 2018 by the author. Licensee MDPI, Basel, Switzerland. This article is an open access article distributed under the terms and conditions of the Creative Commons Attribution (CC BY) license (http://creativecommons.org/licenses/by/4.0/). 